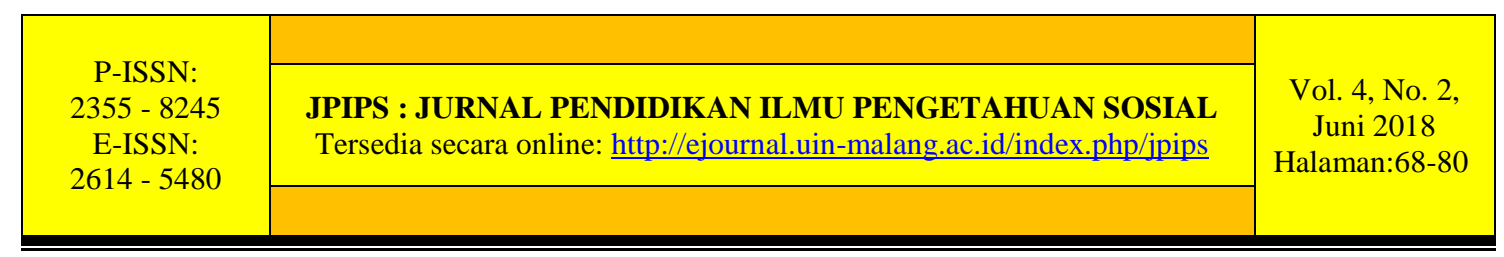

\title{
INTERNALISASI NILAI LIFESTYLE DALAM MEWUJUDKAN MASYARAKAT MADANI (Studi Fenomenologi Gaya Hidup Guru MTsN Di Kota Malang Pasca Sertifikasi)
}

\author{
Ni'matuz Zuhroh \\ Universitas Islam Negeri Maulana Malik Ibrahim Malang \\ zuhroh@pips.uin-malang.ac.id
}

\begin{abstract}
Abstrak: Profesi Guru di Indonesia awalnya dianggap remeh karena hanya mendapatkan gaji yang rendah dan tidak standar jika dibandingkan dengan profesiprofesi lainnya seperti profesi pengacara, profesi dokter, maupun profesi akuntan. Sedangkan di Jepang menjadi guru adalah impian bagi semua kawula muda dikarenakan Profesi Guru sudah disetarakan dengan profesi yang lain sejak tahun 1886. Namun pada Era Pemerintahan Presiden Susilo Bambang Yudhoyono, melalui Undang-undang No. 14 tahun 2005 tentang Guru dan Dosen, nasib Guru diangkat setinggi-tingginya melalui Sertifikasi Guru. Aspek kebutuhan konsumsi dalam mencukupi kebutuhan hidupnya semenjak Guru mendapatkan tunjangan sertifikasi secara fenomena bahwa kondisi Guru lebih baik daripada kondisi sebelumnya. Penelitian ini menggunakan metode kualitatif fenomenologi. Berdasarkan hasil penelitian secara umum para guru tersertifikasi di Madrasah Tsanawiyah Negeri se-Kota Malang mempunyai spirit yang cukup tinggi dalam mengemban tugas yang diwujudkan antara lain dalam bentuk tunjangan sertifikasi difungsikan untuk peningkatan kualitas diri dengan mengikuti pelatihan, workshop dan seminar serta membeli peralatan dan perlengkapan yang memadai untuk menunjang pengajaran.
\end{abstract}

\section{Kata Kunci : Profesi, pengacara, dokter, akuntan, sertifikasi}

Abstract: Teacher professions in Indonesia were initially underestimated because they only received low salaries and were not standard when compared to other professions such as the lawyer's profession, the medical profession, and the accounting profession. Whereas in Japan, being a teacher is a dream for all young people because the Teacher's profession has been equated with other professions since 1886. But in the Era of President Susilo Bambang Yudhoyono's Government, through Law No. 14 of 2005 concerning Teachers and Lecturers, the fate of Master was raised as high as possible through Teacher Certification. The aspect of consumer needs in fulfilling their daily needs since the teacher received a certification allowance is a phenomenon that the condition of the teacher is better than the previous conditions. This research uses phenomenological qualitative methods. Based on the results of the study in general the certified teachers in Madrasah Tsanawiyah Negeri in Malang City have a fairly high spirit in carrying out the tasks which are realized, among others in the form of certification allowances functioned to improve self-quality by attending training, workshops, and seminars and buying equipment and supplies sufficient to support teaching.

Keywords: Professionals, lawyers, doctors, accountants, certifications 


\section{PENDAHULUAN}

Fenomena Guru yang diakui masyarakat bahwa Profesi Guru mudah tercemar dalam arti bahwa semua orang bisa menjadi seorang guru asalkan ia berpengetahuan, akibatnya kualitas pendidikan di Indonesia rendah. Menjadi Guru hanya mendapatkan gaji yang rendah, banyak guru yang tingkat ekonominya miskin, tidak standar jika dibandingkan dengan profesi-profesi yang lainnya. Sedangkan di Jepang menjadi guru adalah impian bagi semua kawula muda dikarenakan Profesi Guru sudah disetarakan dengan profesi yang lain sejak tahun 1886, yaitu guru-guru yang bertugas di Ordinary Normal School, Ordinary Middle School, dan Girl High School. Jenis sertifikat ada empat, yaitu sertifikat kelas satu, kelas dua, kelas tiga dan non kelas (Nur, Agustiar syah,2002). Di Malaysia Sertifikasi Guru dimulai sejak tahun 1990, Demikian juga di negara-negara Asia yang lain gaji guru tidak kalah dengan gaji profesi yang lain. Di Era Pemerintahan Presiden Susilo Bambang Yudhoyono, Guru merupakan profesi yang sama dengan profesi-profesi yang lain ,misalnya Profesi Pengacara, Notaris, Dokter dan Akuntan. Melalui Undang-undang No. 14 tahun 2005 tentang Guru dan Dosen, nasib Guru diangkat setinggi-tingginya melalui Sertifikasi Guru yaitu Guru diberi sertifikat Pendidik sebagai bukti formal pengakuan yang diberikan Guru dan Dosen sebagai tenaga Profesional dan mendapatkan tunjangan kesejahteraan yang layak yang berdampak positif terhadap kehidupan sosialnya. Dalam hal pendidikan, seorang guru yang hidup ditengah masyarakat umum dinilai bisa memberikan pendidikan yang layak bagi anak didiknya dari jenjang paling rendah sampai pendidikan Menengah untuk Guru, Pendidikan Perguruan Tinggi untuk Dosen sehingga tidak jarang kemudian banyak anak-anak muda sekarang yang ingin dan bercita-cita menjadi guru.

Terlepas dari aspek pendidikan, yaitu aspek mencukupi kebutuhan hidupnya misalnya kebutuhan konsumsi baik kebutuhan Primer, sekunder dan tertier. Semenjak Guru mendapatkan tunjangan sertifikasi secara fenomena bahwa kondisi Guru lebih baik daripada kondisi sebelumnya maka tidak heran kemudian banyak Guru yang gaya hidupnya tidak kalah dengan Profesi-profesi yang lain. Dari berbagai penjelasan tersebut diatas peneliti ingin melakukan penelitian dengan Judul INTERNALISASI NILAI LIFESTYLE DALAM MEWUJUDKAN MASYARAKAT MADANI” (Studi Fenomenologi Gaya Hidup Guru MTsN Se Kota Malang Pasca Sertifikasi).

Dari latar belakang pemikiran di atas, maka dalam penelitian ini difokuskan pada pertanyaan- pertanyaan tentang: Bagaimana Internalisasi Nilai dalam mewujudkan masyarakat Madani melalui tunjangan Sertifikasi bagi Guru dalam menitih karirnya dan kehidupan sosialnya? Bagaimana Model Gaya Hidup yang paling dominan yang dilakukan oleh Guru MTsN Di Kota Malang Pascasertifikasi? dan Bagaimana Guru dalam proses Adaptasi Budaya Melalui Gaya hidupnya Pasca Sertifikasi?

\section{METODE}

Penelitian ini di lakukan di Madrasah Tsanawiyah Negeri se-Kota Malang, yaitu MTsN 1 Kota Malang dan MTsN 2 Kota Malang dengan durasi waktu penelitian selama 6-8 bulan.

Tabel 1 Lokasi Penelitian

\begin{tabular}{llll}
\hline No & Lokasi Penelitian & Alamat & No. Telepon \\
\hline 1 & MTsN 1 Kota Malang & Jl. Bandung No. 7C Malang & $0341-587087$ \\
2 & MTsN 2 Kota Malang & Jl. Raya Cemoro Kandang & $0341-711500$ \\
& & 77 & \\
\hline
\end{tabular}


Pendekatan penelitian yang telah digunakan untuk mencapai tujuan penelitian utamanya dengan menggunakan metode kualitatif dengan sifat penelitian fenomenologi. Menurut Moleong (2007), pendekatan kualitatif menggunakan perspektif emic yaitu suatu perpektif dimana peneliti menganggap perilaku manusia terpola dalam sistem pola itu sendiri, peneliti meninjau dari segi subyek, situasi, dan latar yang dihadapinya.

Menurut Husserl (Raho, 2007), fenomologi adalah suatu studi tentang kesadaran dari perspektif pokok seseorang. Fenomologi merupakan cara untuk memahami struktur realitas yang berkaitan langsung dengan pengalaman manusia. Penelitian fenomologi memungkinkan peneliti untuk menganalisis kejadian sehari-hari yang dilakukan subyek, karena realitas sehari-hari itulah yang menjadi gambaran peneliti mengenai realitas subyek. Inti dari penelitian fenomenologi adalah membiarakan realitas menampakan diri dan tampil di hadapan peneliti apa adanya. Fenomenologi merupakan pandangan berfikir yang menekankan pada fokus kepada pengalaman-pengalaman subyektif manusia dan interpretasi-interpretasi dunia. Dalam hal ini, para fenomologis ingin memahami bagaimana dunia muncul pada orang lain. (Moleong, 2007). Menurut Berger yang dikutip Basrowi dan Soenyono (2004), tugas fenomologi adalah menganalisis kenyataan-kenyataan sosial. Analisis terhadap realitas sosial akan memasukan konsep interpretasi pada praktek kehidupan sehari-hari. Jadi prinsip fenomenologi yang bisa di gunakan oleh peneliti kontemporer, yaitu: (1) peneliti menempatkan subyek terteliti sebagai subyek yang kritis dan problematik; (2) individu bertindak secara praktis atas dasar pilihan rasional; (3) menempatkan pemahaman seseorang tidak hanya berasal dari pengaruh dalam dirinya, tetapi juga merupakan produk dari kesadaran terhadap orng lain. Dengan kata lain, tindakan manusia proses internalisasi dan eksternalisasi.

Prosedur utama fenomenologi dikenal dengan istilah apoche. yaitu saat seorang peneliti mengenali secara sementara menyingkirkan semua pandangan pribadi (mereduksi). Agar data yang di dapat di lapang benar-benar menggambarkan realitas yang dilakukan subyek, maka dalam penelitian fenomenologi peneliti harus melakukan reduksi. Reduksi adalah tahap dimana peneliti harus meletakan dugaan-dugaan sementara tentang subyek dan tentang apa yang akan terjadi dilapang sebelum peneliti melihat fakta di lapang. Jadi seorang peneliti tidak boleh membuat dugaan sementara, karena yang ditakutkan dari adanya dugaan sementara adalah saat dugaan itu mempengaruhi apa yang peneliti di lapang. Dalam pelaksanaan penelitian yang dilakukan, karena peneliti juga manusia yang mempunyai pikiran dan dugaan, persaratan untuk tidak mempunyai dugaan sementara sulit untuk dilaksanakann namun setidaknya peneliti telah berusaha untuk meniadakan dugaan-dugaan sementara yang timbul pada saat penelitian dilakukan.

Dalam proses penelitian lapangan, dengan menggunakan metode fenomenologi telah mengharuskan peneliti untuk mampu dalam berfikir secara fenomenologis. Berfikir secara fenomenologis artinya peneliti telah melihat obyek penelitian apa adanya dan membiarkan obyek penelitian menampilkan seluruh dirinya. dari sanalah peneliti mampu melihat suatu fenomena secara menyeluruh. Dengan berfikir secara fenomenologis, peneliti telah menunda segala bentuk penilaian, dan memberikan kesempatan pada obyek penelitian yaitu fenomena yang peneliti angkat.

Populasi dalam penelitian ini adalah seluruh guru tersertifikasi di MTsN 1 dan MTsN 2 Kota Malang, sebagai berikut: 
Tabel 2 Data Populasi Penelitian

\begin{tabular}{lllll}
\hline No & Lokasi Penelitian & Jumlah Guru & Tersertifikasi & Sampel \\
\hline 1 & MTsN 1 Kota Malang & 59 & 50 & 15 \\
2 & MTsN 2 Kota Malang & 48 & 42 & 15 \\
\hline Jumlah & $\mathbf{1 1 8}$ & $\mathbf{9 2}$ & $\mathbf{3 0}$ \\
\hline
\end{tabular}

Data dikumpulkan dengan beberapa teknik, yaitu (Prasetyo, 2006) mengunakan wawancara, angket dan dokumentasi. Setelah data hasil penelitian dikumpulkan oleh peneliti, maka langkah selanjutnya adalah menganalisis yang diperoleh dengan cara sebagai berikut:

1. Editing, ini berarti bahwa semua angket harus diteliti satu persatu tentang kelengkapan dan kebenaran pengisian angket, sehingga terhindar dari kekeliruan dan kesalahan.

2. Data Coding atau pengkodean data, maksudnya ialah suatu proses penyusunan secara sistematis data mentah (yang ada di questioner) ke dalam bentuk yang mudah dibaca oleh mesin pengolah data, seperti komputer. Sedangkan hurufhuruf yang ada pada pernyataan diubah menjadi kode angka.

3. Data entering (pemindahan data ke komputer), adalah memindahkan data yang telah diubah menjadi kode kedalam mesin pengolah data.

4. Data cleaning (pembersihan data), adalah memastikan seluruh data yang telah dimasukkan ke dalam mesin pengolah data sudah sesuai dengan sebenarnya (Prasetyo, 2006:172).

5. Distribusi frekuensi, adapun langkah-langkahnya adalah: Perhitungan dengan data ini, dapat dilakukan dengan menghitung frekuensi data tersebut, kemudian dipresentasekan. Untuk menghitung sebaran presentase dari frekuensi tersebut, digunakan rumus:

Keterangan:

$$
p=\frac{F}{N} \times 100
$$

$\mathrm{P}=$ angka prosentase

$\mathrm{F}=$ fekuensi

$\mathrm{N}=$ Number of case (jumlah kejadian). (Sudijono, 2010:43)

Sedangkan ketentuan interval data, sebagaimana yang diungkapkan Suharsimi Arikunto (2010:269):, sebagai berikut:

1. Sangat Tinggi, jika nilai yang diperoleh berada pada interval $81-100 \%$

2. Tinggi, jika nilai yang diperoleh berada pada interval $61-80 \%$

3. Cukup tinggi, jika nilai yang diperoleh berada pada interval $41-60 \%$

4. Kurang tinggi, jika nilai yang diperoleh berada pada interval $21-40 \%$

5. Tidak tinggi, jika nilai yang diperoleh berada pada interval $0-20 \%$

\section{HASIL DAN PEMBAHASAN}

\section{Hasil}

\section{Gambaran Umum Objek Penelitian}

\section{a. MTsN 1 Kota Malang}

Madrasah ini terletak di pusat Kota Madya Malang yang dikelilingi oleh lembaga-lembaga pendidikan unggul mulai jenjang pra sekolah sampai perguruan tinggi. Seperti, TK/BA Restu 1, MIN 1 Kota Malang, SDI Sabilillah, SD Brawijaya 
Smart School, SD Plus Al-Kautsar, Universitas Negeri Malang, Universitas Brawijaya dan Universitas Islam Negeri Maulana Malik Ibrahim Malang serta lembaga pendidikan formal lainnya.

Selain itu, madrasah ini juga dikelilingi oleh tempat wisata dan pusat perbelanjaan serta mall. Seperti, Malang Town Square, MX Mall, Mall Olimpic Garden, Ramayana, Alun-alun Kota dan Hawai.

b. MTsN 2 Kota Malang

Berbeda dengan MTsN 1 Kota Malang, madrasah ini terletak lebih jauh dari jantung kota Madya Malang dan cenderung berada di daerah pedesaan. Kondisi demikian juga akan mempengaruhi baik secara langsung maupun tidak langsung terhadap pola hidup para guru di madrasah tersebut.

\section{Karakteristik Responden}

Penelitian ini dilakukan di Madrasah Tsanawiyah Negeri se-Kota Malang yang terdiri dari 2 madrasah, yaitu MTsN 1 Kota Malang dan MTsN 2 Kota Malang. Dimana, guru tersertifikasi menjadi subjek atau responden penelitian. Angket yang didistribusikan sebanyak 50 eksemplar, namun yang kembali hanya 30 eksemplar dengan durasi waktu 1 minggu (18-23 September 2017). Angket yang kembali selanjutnya diolah untuk mengetahui hasilnya.

Tabel 3 Jenis Kelamin Responden

\begin{tabular}{llllll}
\hline \multirow{2}{*}{ Valid } & & & & Cumulative \\
\cline { 2 - 6 } & Laki-Laki & 12 & 40.0 & 40.0 & 40.0 \\
& Permpuan & 18 & 60.0 & 60.0 & 100.0 \\
\cline { 2 - 6 } & Total & 30 & 100.0 & 100.0 & \\
\cline { 2 - 6 }
\end{tabular}

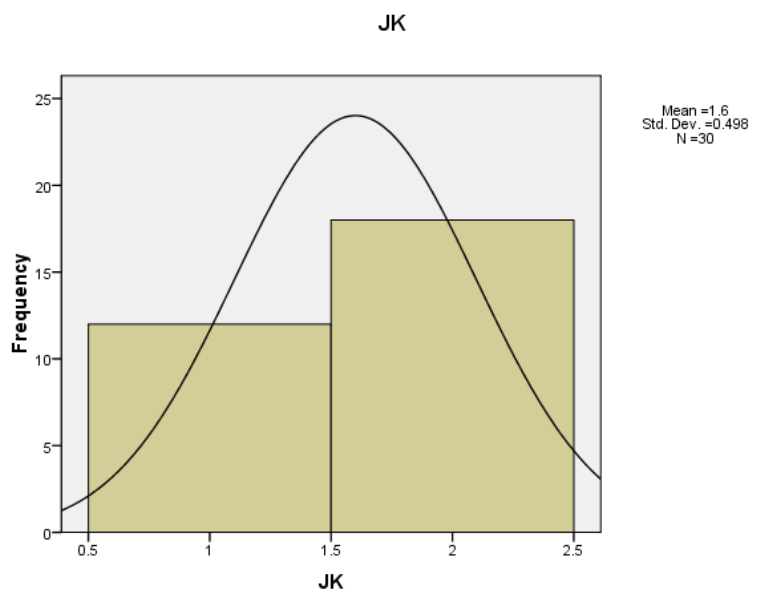

Tabel 3 Jenis Kelamin Responden

Karakteristik responden berdasarkan jenis kelamin, yaitu 12 guru laki-laki dan 18 guru perempuan dengan total 30 guru tersertifikasi sebagai subjek penelitian.

\section{Uji Validitas dan Reliabilitas}

Pengujian validitas yang digunakan dalam penelitian ini adalah korelasi Product Moment Person dan di anggap valid jika nilai $r \geq 0,349$ maka instrumen tersebut dapat dikatakan valid dan apabila nilai $r \leq 0,349$ maka instrumen tersebut dikatakan tidak 
valid. Dasar penentuan kevalidan item pernyataan/pertanyaan dalam instrumen dengan membandingkan nilai $\mathrm{r}_{\text {tabel }}$ dengan harga Corrected Item-Total Correlation. Apabila nilai $r_{\text {hitung }}>r_{\text {tabel }}$ maka item pertanyaan/pernyataan dalam angket dinyatakan valid, namun bila nilai $r_{\text {hitung }}<r_{\text {tabel }}$ maka berlaku kesimpulan sebaliknya. Nilai $r_{\text {tabel }}=0.349$ dan probabilitas 0,05 maka 15 item pertanyaan/pernyataan dalam instrumen dinyatakan valid, dengan demikian angket dapat dijadikan alat yang sah untuk mengumpulkan data primer dari responden. Setelah mengetahui kevalidan dan keabsahan isi angket untuk dijadikan alat ukur, maka perlu dilakukan uji relibitas guna mengetahui tingkat keakuratan instrumen dalam mengumpulkan data dari responden.

Reliabilitas alat ukur adalah kesesuaian alat ukur dengan yang diukur, sehingga alat ukur itu dapat dipercaya atau dapat diandalkan. Mendesain instrumen penelitian yang reliabel adalah tujuan yang ingin dicapai oleh setiap peneliti. Hal ini karena peneliti tidak ingin proses pengumpulan data akan gagal karena peneliti memiliki instrument yang buruk. Selain itu karena instrument penelitian (khususnya adalah angket) adalah wakil satu-satunya peneliti di lapangan sehingga keterpercayaan instrumen penelitian sebagai alat yang betul-betul mewakili peneliti, benar-benar tidak dapat diabaikan. Oleh karena itu, alat-alat ukur yang dipakai haruslah memiliki sentivitas (kepekaan) yang tinggi terhadap data yang dihadapi, artinya, alat ukur juga harus reliabel.

Dalam pengujian ini dilakukan dengan cara one shot atau pengukuran sekali saja. Program SPSS memberikan fasilitas untuk realibilitas dengan uji statistic. Instrumen dikatakan reliabel, jika hasil perhitungan memiliki koefisien keandalan (reliabilitas) sebesar $\alpha=0,05$ atau lebih. Untuk itu, perbandingan antara harga Cronbach's Alpha Based on Standardized Items dengan nilai rtabel cara tepat mengetahui tingkat keandalan instrumen. Tabel 4.3 harga keandalan yang diperoleh sebesar 0,742 nilai yang cukup tinggi sedangkan nilai rtabel $=0,349$ artinya secara keseluruhan item pertanyaan dinyatakan reliabel. Kemudian untuk mengetahui tingkat keandalan per-item pertanyaan/pernyatan dapat membandingkan nilai Cronbach's Alpha if Item Deleted dengan rtabel jika nilai hitungnya > rtabel maka item yang dibandingkan dinayatakan reliabel. Contoh item 3 mempunyai nilai $0.719>0.349$ bermakna item tersebut dinyatakan reliable.

Tunjangan sertifikasi dapat membuat guru menjadi lebih profesional dalam pengajaran dan berkarya, $43.3 \%$ menjawab setuju dan $56.7 \%$ menjawab tidak setuju. Tunjangan profesi memotivasi diri untuk bersikap disiplin dan mengajar dengan lebih baik, 96.7\% guru menyatakan diri telah melakukan yang terbaik untuk siswa, namun $3.3 \%$ masih merasa belum optimal.Tunjangan sertifikasi dipergunakan untuk belanja yang berkaitan dengan profesi sebagai guru (beli buku, beli laptop, TOT dan lain-lain) terlihat bahwa 90\% telah membelanjakan tunjangannya sesuai peruntukannya, yaitu pengembangan diri dan hanya $10 \%$ yang masih sebagian tunjangannya untuk keperluan yang lain, seperti melunasi hutang, membiayai keluarga yang sedang sakit dan dibuat modal usaha. Tunjangan profesi guru telah mengubah pola konsumsi anak dan keluarga, dimana 53.3\% menyatakan diri bahwa anak-anak para guru mampu terpenuhi keinginannya untuk memperoleh barang yang diinginkan. Namun, 46.7\% guru menyatakan diri bahwa tidak semua tunjangan digunakan untuk kebutuhan anak. Artinya, guru-guru yang telah sertifikasi menggunakan uangnya untuk keperluan profesionalitas diri.

Kecenderungan seseorang untuk mempunyai barang bermerk adalah suatu sifat manusiawi, begitu pula dengan beberapa guru yang telah memperoleh tunjangan 
sertifikasi ada keinginan untuk memiliki barang yang telah rusak (tentu bermerk). Sebesar $26.7 \%$ guru memanfaatkan tunjangannya untuk membeli barang yang sama dengan yang dimiliki. Namun, $73.3 \%$ guru menyatakan diri tidak menggunakan uang nya untuk membeli produk yang sama dengan yang telah dimiliki. Pola konsumsi guru setelah memperoleh tunjangan, yaitu $83.4 \%$ berpikir dua kali untuk membeli barang, pakaian, makanan atau kendaraan. Secara tidak langsung, para guru MTsN se-Kota Malang memiliki sikap hemat dan hanya $16.6 \%$ yang bersikap sedikit hedonis namun masih dalam taraf kewajaran. Sikap guru dalam membeli barang dengan mempertimbangkan harga barang, dimana $56.6 \%$ guru sangat mempertimbangkan harga dalam membeli barang. Apabila barang tersebut dirasa mahal, maka guru tidak akan membeli dan mencari barang pengganti. Namun, $43.4 \%$ guru lainnya tidak mempertimbangkan harga dalam membeli produk, karena merupakan kebutuhan untuk menunjang kerja atau kualitas produk yang baik. Sebesar $36.7 \%$ guru masih membeli barang yang belum sesuai kebutuhan, namun $63.3 \%$ guru menggunakan uang tunjangannya untuk membeli barang-barang yang berguna dan menunjang profesinya.

Satu indicator pola kosnumsi guru setelah menerima tunjangan, dimana $83.3 \%$ guru lebih suka belanja di pasar-pasar tradisional dari pada di Mall atau supermarket. Hanya $16.7 \%$ guru yang belanja bulanannya di Mall/supermarket. Gaya hidup para guru Tsanawiyah Negeri di Kota Malang tergolong relatif biasa-biasa saja (sederhana), dimana $73.4 \%$ guru tidak terlalu memikirkan merk dalam membeli produk. Namun, $26.6 \%$ guru masih mempertimbangkan merk dalam membeli barang tentu hal ini tidak terlepas dari budaya dan lingkungan kerja. Akhlak, keimana dan ketaqwaan para guruguru di Madrasah Tsanawiyah Negeri Kota Malang tergolong cukup baik, mereka meyakini bahwa bukanlah pujian orang yang menjadikan seseorang diangkat derajatnya oleh Allah bukan karena pakaian bermerk dan bukan pula kendaraan terbaru. Realita ini tercermin terbukti dari hasil penelitian, sebanyak $73.3 \%$ guru tidak mengharapkan pujian orang lain dari penampilan maupun pakaian yang digunakannya. Sedangkan $24.7 \%$ guru masih ada yang senang menggunakan barang bermerk sebagai bentuk status diri.

Pola hidup para guru pasca tersertifikasi untuk keluarganya, dimana $63.4 \%$ guru lebih suka menyekolahkan keluarganya di sekolah yang unggul namun tidak mahal. Karena bagi mereka sekolah mahal bukanlah ukuran keberhasilan sang anak. Sedangkan $36.6 \%$ guru mempunyai keinginan keluarganya bersekolah di sekolah favorit dan biaya lebih mahal, karean anggapannya sekolah dengan biaya lebih mahal maka anak akan memperoleh fasilitas yang memadai dan status hidupnya lebih tinggi. Guru merasa bangga bila menggunakan produk bermerk, terlihat bahwa $60 \%$ atau sebagian besar guru tidak suka menggunakan barang-barang bermerk sebagai suatu kebanggaan. Sedangkan $40 \%$ masih berfikir bahwa menggunakan barang bermerk dapat menaikkan kelas status sosial.

Sebagian besar guru menyatakan diri tidak suka menggunakan aksesoris baru dan branded, yaitu $63.3 \%$ dan hanya $36.7 \%$ suka menggunakan aksesoris yang berbeda dengan guru yang lain (tampil beda). Guru mengharapkan pujian orang lain setiap menggunakan barang yang baru bahwa guru tersertifikasi menyatakan diri tidak mengharapkan ada pujian orang lain sebesar $96.7 \%$ dan hanya 1 orang guru yang masih berharap demikian. 


\section{Pembahasan \\ Gaya Hidup dan Profesionalisme Guru MTsN se-Kota Malang}

Profesi guru sebagai pekerjaan mulia tidak terbantahkan. Dari sudut pandang teologis, terma guru senada dengan al-murabbi, al-mu'allim, al-muadib, al-rasikhun fi al-'ilmi, ulul albab dan masih banyak lagi istilah lain yang seluruhnya menunjukkan nilai keluhuran. Berkat keteladanan yang terpancar melalui laku keseharian, masyarakat menempatkan guru ke dalam strata sosial yang cukup prestise, bahkan cenderung tinggi. Apalagi, pasca berlakunya program sertifikasi, memungkinkan guru untuk hidup lebih sejahtera secara ekonomi. Tidak aneh, jika kita melihat fenomena perubahan gaya hidup guru.

Citra guru, pada satu sisi tergambar dalam nyanyian Oemar Bakrie; yang berangkat ke sekolah penuh semangat dengan modal sepeda butut. Di sisi lain, guru dilukiskan oleh "Keluarga Bakrie" lainnya; yang berlimpah harta dan kaya raya. Ihwal ini mengindikasikan bahwa sertifikasi guru justru menimbulkan diskriminasi baru antara guru yang sudah dengan yang belum bersertifikat. Padahal, belum ada jaminan pasti, jika guru yang telah mendapatkan sertifikat profesi, secara kualitatif lebih baik dari guru yang belum bersertifikat. Hakikatnya, sertifikat hanyalah bentuk formalitas simbolik untuk merepresentasikan guru profesional, sedangkan substansi profesionalisme terletak pada kompetensi.

"Pahlawan Tanpa Tanda Jasa" adalah salah satu julukan yang dapat disematkan kepada sosok guru. Julukan ini mengisyaratkan bahwa betapa besar peran dan jasa yang dilakukan oleh guru selayaknya seorang pahlawan. Namun, penghargaan terhadap guru nyatanya tidaklah sebanding dengan besarnya jasa yang telah diberikan. Guru adalah sosok yang dengan tulus mencurahkan sebagian waktu yang dimilikinya untuk mengajar dan mendidik siswa, sementara dari sisi finansial yang didapatkan sangat jauh dari harapan. Gaji seorang guru rasanya terlalu jauh untuk mencapai kesejahteraan hidup layak sebagaimana profesi lainnya. Hal itulah kiranya menjadi salah satu yang melatarbelakangi mengapa guru disebut sebagai pahlawan tanpa tanda jasa.

Tingkat kesejahteraan guru yang sudah menikmati tunjangan profesi sebesar satu kali gaji pokok memang membaik. Setidaknya, mereka sudah tidak lagi direpotkan urusan dapur. Model dari guru-guru yang telah memperoleh manfaat kesejahteraan berupa rapelan tunjangan profesi. Mendapat pendidikan dan latihan profesi guru dengan pola karantina dan asupan tunjangan profesi bulanan senilai besaran gaji pokok PNS semestinya menjadi variabel motivasi untuk memperbaiki kualitas mengajar.

Guru semakin memacu diri melakukan perubahan perbaikan seperti konsisten meng-update kemampuan pedagogik, metode dan media pembelajaran, menampilkan semangat dan kualitas kerja yang cukup tinggi, disiplin mengajar, tidak menyibukkan diri dengan kegiatan-kegiatan nyambi yang mengurangi fokus perhatian terhadap tugas misalnya berjualan, atau mengurangi kesibukan atas banyaknya jam mengajar, mata pelajaran dan jumlah sekolah.

Motivasi utama guru ingin segera ikut sertifikasi adalah terkait dengan finansial, yaitu untuk mendapatkan tunjangan profesi. Agar segera dapat uang untuk memenuhi kebutuhan hidup, Biar dapat tunjangan untuk bayar biaya kuliah, biaya pedidikan anak, dapat di gunakan untuk merenovasi rumah, untuk membayar hutang, untuk pergi haji.

Dengan memiliki sertifikat pendidik, guru akan memperoleh penghasilan di atas kebutuhan minimum, meliputi: gaji pokok, tunjangan yang melekat pada gaji, serta penghasilan lain berupa tunjangan profesi, tunjangan fungsional, tunjangan khusus, dan 
maslahat tambahan yang terkait dengan tugasnya sebagai guru yang ditetapkan dengan prinsip penghargaan atas dasar prestasi.

Guru yang diangkat oleh satuan pendidikan yang diselenggarakan oleh Pemerintah atau Pemerintah Daerah diberi gaji sesuai dengan peraturan perundangundangan, sementara guru yang diangkat oleh satuan pendidikan yang diselenggarakan oleh masyarakat diberi gaji berdasarkan perjanjian kerja atau kesepakatan kerja bersama. kemampuannya dengan cara menempuh pendidikan yang lebih tinggi. Guru juga harus terus belajar, agar tidak merasa kekeringan dalam bidang ilmu pengetahuan.

Dewasa ini banyak yang juga senang untuk mengejar penampilan daripada meningkatkan kompetensi profesi sebagai guru. Menjadi kreditor dari sebuah bank atau pelanggan counter HP adalah juga prilaku gaya hidup mereka. Mengambil pinjaman uang untuk membeli mobil, walaupun mobil second. Tidak jarang, memiliki mobil belum jadi kebutuhan tetapi karena kompetisi penampilan maka mereka juga terdorong untuk memiliki. Melakukan perawatan mobil berjam-jam hingga menyita waktu yang seharusnya sebagai quota untuk tujuan pendidikan. Guru- guru perempuan juga berlomba untuk membeli assessories, pakaian, perhiasaan agar mereka bisa tampil menarik bak bintang iklan televisi, maka waktu yang dihabiskan untuk memenuhi nafsu konsumerisme juga telah menyita waktu yang seharusnya dibaktikan untuk pendidikan. Karena kesibukan untuk memenuhi kebutuhan hidup dan kesenangan dunia, sebagian guru cendrung kehilangan waktu untuk menyiapkan diri menjadi guru yang professional. Cukup banyak guru tak punya waktu untuk belajar, menyiapkan perangkat pengajaran, menyiapkan soal-soal ujian dan memeriksa ujian dan pekerjaan siswa. Tetapi untuk berbagi gossip tetap selalu ada waktu.

Tidaklah berdosa bila seorang guru juga mengejar dan memenuhi kebutuhan penampilan. Guru juga manusia biasa, mereka juga punya kebutuhan mulai dari kebutuhan primer, sekunder dan kebutuhan luks. Atau mereka juga perlu memenuhi kebutuhan fisik, kebutuhan rasa aman, kebutuhan psikologi sampai kepada kebutuhan untuk aktualisasi diri. Dan selayaknya guru juga bisa meluncur dengan mobil sedan, hingga sebutan "Oemar Bakri" yang pergi mengajar dengan mendayung sepeda kumbang tidak melekat lagi. Tapi semua itu harus dibarengi juga dengan kepedulian untuk menajamkan kemampuan kompetensi mereka sebagai guru yang professional Untuk menjadi profesional, seorang guru dituntut memiliki empat hal, yakni:

a. Guru mempunyai komitmen pada siswa dan proses belajarnya. Ini berarti bahwa komitmen tertinggi guru adalah kepada kepentingan siswanya.

b. Guru menguasai secara mendalam bahan/mata pelajaran yang diajarkan serta cara mengajarkannya kepada siswa. Bagi guru, hal ini meryupakan dua hal yang tidak dapat dipisahkan.

c. Guru bertanggung jawab memantau hasil belajar siswa melalui berbagai teknik evaluasi, mulai cara pengamatan dalam perilaku siswa sampau tes hasil belajar.

d. Guru mampu berpikir sistematis tentang apa yang dilakukannya, dan belajar dari pengalamannya. Artinya, harus selalu ada waktu untuk guru guna mengadakan refleksi dan koreksi terhadap apa yang telah dilakukannya. Untuk bisa belajar dari pengalaman, ia harus tahu mana yang benar dan salah, serta baik dan buruk dampaknya pada proses belajar siswa.

Terlepas dari banyaknya persoalan yang dihadapi guru dalam hidup kesehariannya, guru tetaplah sosok penting yang cukup menentukan dalam proses pembelajaran. Walaupun sekarang ini ada berbagai sumber belajar alternatif yang lebih kaya, seperti buku, jurnal, majalah, internet, maupun sumber belajar lainnya, guru tetap 
menjadi kunci untuk optimalisasi sumber-sumber belajar yang ada. Guru tetap menjadi sumber belajar yang utama. Tanpa kehadiran guru, proses pembelajaran tidak akan dapat berjalan secara maksimal. Orang mungkin dapat belajar mandiri (autodidak) secara maksimal sehingga kemudian menjadi seorang ahli dalam bidang tertentu. Akan tetapi, autodidak tetap akan berbeda hasilnya dengan mereka yang juga sama-sama berusaha dengan maksimal di bawah bimbingan guru.

Guru atau pendidik merupakan sosok yang seharusnya mempunyai banyak ilmu, mau mengamalkan dengan sungguh-sungguh ilmu yang dimilikinya dalam proses pembelajaran dalam makna yang luas, toleran, dan senantiasa berusaha menjadikan siswanya memiliki kehidupan yang lebih baik. Secara prinsip, mereka yang disebut sebagai guru bukanlah hanya mereka yang memiliki kualifikasi keguruan secara formal yang diperoleh lewat jenjang pendidikan di perguruan tinggi saja, tetapi yang terpenting adalah mereka yang mempunyai kompetensi keilmuan tertentu dan dapat menjadikan orang lain pandai dalam matra kognitif, afektif, dan psikomotorik. Matra kognitif menjadikan siswa cerdas dalam aspek intelektualnya, matra afektif menjadikan siswa mempunyai sikap dan perilaku yang sopan, dan matra psikomotorik menjadikan siswa terampil dalam melaksanakan aktifitas secara efektif dan efisien, serta tepat guna. Guru tidaklah cerdas untuk dirinya sendiri namun dapat menyebarkan virus kecerdasan untuk orang lain (anak didiknya).

Di sinilah letak pentingnya peranan seorang guru. Sehingga bukan hal yang terlalu berlebihan jika ada penilaian bahwa berhasil atau tidaknya proses pendidikan tergantung kepada peranan guru. Walaupun peranannya sangat menentukan, namun harus disadari bahwasanya guru bukanlah satu-satunya penentu keberhasilan atau kegagalan pembelajaran. Sebab, keberhasilan atau kegagalan pembelajaran dipengaruhi oleh beragam faktor yang saling berkaitan antara satu dengan lainnya. Oleh karena itu, guru harus menghindari sikap merasa sebagai pihak paling berjasa dan paling menentukan dalam keberhasilan pembelajaran. Begitulah kehebatan dan pengaruh guru pada sebuah lembaga di mana ia bernaung. Hanry Adam, seorang sejarahwan terkemuka, sebagaimana dikutip M. Nurdin (2004:32), mengatakan: A teacher effect eternity, he can never tell where his influence stops (Seorang guru itu berdampak abadi, ia tidak pernah tahu dimana pengaruhnya itu berhenti).

Secara umum para guru tersertifikasi di Madrasah Tsanawiyah Negeri se-Kota Malang mempunyai spirit yang cukup tinggi dalam mengemban tugas. Hal ini senada dengan pendapat Ngainun Naim (2009:6-9) bahwa guru professional itu harus mempunyai motivasi tinggi. Spirit yang tinggi dimiliki oleh para guru MTsN se-Kota Malang diwujudkan dalam bentuk:

a. Keluasan wawasan dan pengetahuan yang dimiliki. Oleh karena itu, seorang guru harus selalu berusaha secara maksimal untuk meningkatkan wawasan dan pengetahuannya. Dalam pendidikan, prinsip belajar sepanjang hayat (long life education) harus menjadi bagian tidak terpisah dari kehidupan seorang guru. Prinsip belajar sepanjang hayat tidak hanya berlaku bagi siswa, tetapi juga bagi guru. Guru yang justru harus menjadi teladan dari prinsip ini. Sebelum mencerdaskan, guru harus mencerdaskan dirinya terlebih dahulu. Dinamika dan perkembangan yang berlangsung sedemikian cepat mengharuskan seorang guru merespon secara kreatif. Tanpa kemauan untuk selalu meningkatkan wawasan dan pengetahuannya, maka apa yang diajarkan guru akan kehilangan perspektif yang mencerahkan. Tidak akan ada nuansa, cara pandang, dan kontekstualisasi dari apa yang diajarkan. Guru yang tidak 
pernah mau meng-up-grade pengetahuannya ibarat sebuah kaset yang terus-menerus diputar ulang tanpa ada revisi dan penambahan sama sekali.

b. Mampu menyampaikan ilmu yang benar dan tidak mengada-ada dan berdasar pada al-Qur' an dan Hadits

c. Bersikap objektif dalam mengahdapi persoalan dan penilaian peserta didik

d. Tunjangan sertifikasi difungsikan untuk peningkatan kualitas diri dengan mengikuti pelatihan, workshop dan seminar serta membeli peralatan dan perlengkapan yang memadai untuk menunjang pengajaran.

e. Memiliki loyalitas, motivasi dan dedikasi tinggi terhadap pengembangan lembaga dan mutu lulusan, hal ini dibuktikan dengan mengajar penuh disiplin.

f. Update informasi, pengetahuan dan teknologi pembelajaran.

g. Bersikap sederhana dan tidak menampilkan gaya hidup hedonis.

h. Menunjukkan sikap wibawa, teladan dan bertanggungjawab.

\section{Internalisasi Nilai Lifestyle dalam Mewujudkan Masyarakat Madani}

Pada masa sekarang ini Indonesia membutuhkan dan tengah mengarahkan segenap aspek pembangunan pada berkembangnya masyarakat madani sebagaimana amanah dan tujuan negara, yaitu: memajukan kesejahteraan umum, mencerdaskan kehidupan bangsa, dan ikut melaksanakan ketertiban dunia yang berdasarkan kemerdekaan, perdamaian abadi dan keadilan sosial. Kondisi Indonesia yang dilanda euphoria demokrasi, semangat otonomi daerah, dan derasnya globalisasi membutuhkan masyarakat yang mempunyai kemauan dan kemampuan hidup bersama dalam sikap saling menghargai dan toleransi dalam kemajemukan yang tidak saling mengekslusifkan terhadap berbagai suku, agama, bahasa, ras, dan adat yang berbeda. Kepedulian, kesantunan, dan setia kawan merupakan sikap yang sekaligus menjadi prasaran yang diperlukan bangsa Indonesia.

Pengembangan masyarakat madani di Indonesia tidak bisa dipisahkan dari pengalaman sejarah bangsa Indonesia sendiri. Kebudayaan, adat istiadat, pandangan hidup, kebiasaan, rasa senasib sepenanggungan, cita-cita dan hasrat bersama sebagai warga dan sebagai bangsa, tidak mungkin lepas dari lingkungan serta sejarahnya. Lingkungan dan akar sejarah kita, warga dan bangsa Indonesia, sudah diketahui baik kekurangan maupun kelemahan, juga diketahui kelebihan dan keunggulannya. Di antara keunggulan bangsa Indonesia, adalah berhasilnya proses akulturasi dan inkulturasi yang kritis dan konstruktif. Pada saat ini, ada pertimbangan lain mengapa pengembangan masyarakat madani harus secara khusus diberi perhatian. Kita hidup dalam jaman, di mana interaksi tidak saja berlangsung secara domestik dan regional, tetapi sekaligus secara global. Dari idiom yang kita pakai, kemauan dan kemampuan kita untuk adaptasi, akulturasi, dan inkulturasi, lebih-lebih lagi sangat kita perlukan dalam masa reformasi menuju demokratisasi dewasa ini.

Masyarakat madani Indonesia adalah masyarakat yang memegang teguh ideologi yang benar, berakhlak mulia, secara politik ekonomi dan budaya bersifat mandiri, serta memiliki pemerintahan demokratis. Secara umum ada 3 (tiga) karakteristik dasar dalam masyarakat madani, yaitu:

a. Diakuinya semangat pluralisme, artinya pluralisme telah menjadi sebuah keniscayaan yang tidak dapat dielakkan sehingga mau tidak, pluralitas telah menjadi kaidah yang abadi. Pluralisme bertujuan mencerdaskan umat melalui perbedaan konstruktif dan dinamis serta merupakan sumber dan motivator terwujudnya kreativitas, yang terancam keberadaannya jika tidak terdapat perbedaan. Satu hal yang menjadi catatan 
penting bagi kita adalah sebuah perbedaan yang kosmopolit akan tercipta manakala manusia memiliki sikap inklusif dan mempunyai kemampuan (ability) menyesuaikan diri terhadap lingkungan sekitar. Sedangkan menurut Nurcholis Madjid, konsep pluralisme merupakan prasyarat bagi tegaknya masyarakat madani. Pluralisme menurutnya adalah pertalian sejati kebhinkekaan dalam ikatan-ikatan keadaban (genuine engagement of diversities within the bonds of civility), (Madjid, 2000).

b. Tingginya sikap toleransi baik terhadap saudara sesama agama maupun terhadap umat agama lain. Secara sederhana toleransi dapat diartikan sebagai sikap suka mendengar serta menghargai pendapat dan pendirian orang lain.

c. Tegaknya prinsip demokrasi.

Pendidikan memiliki hubungan yang sangat erat dengan masyarakat madani karena pada dasarnya, pendidikan adalah hal yang sangat diperlukan dalam mewujudkan masyarakat beradab dalam membangun, menjalani, dan mamaknai kehidupannya. Upaya untuk mengaktualisasikan masyarakat madani yang dilakukan oleh para guru di MTsN se-Kota Malang, antara lain:

a. Mengajarkan peserta didik berbuat baik kepada sesame, menampilkan telada baik dengan bersikap hemat dan tidak boros.

b. Menghadirkan proses pembelajaran yang demokratis, seperti melakukan penilaian dengan objektif dan transparan melalui kontrak belajar.

c. Melaksanakan proses KBM yang menyenangkan dengan metode diskusi, jigsaw yang dapat menghargai pendapat temannya sendiri.

d. Bersikap disiplin, jujur dan bertanggungjawab dalam melakukan proses KBM.

e. Memamtuhi peraturan dan ketentuan sekolah.

f. Menanamkan demokrasi sejak dini kepada peserta didik, dengan melakukan pemilihan struktur kelas secara terbuka.

g. Mengajarkan peserta didik suri tauladan berdasarkan al-Qur'an dan Hadits.

\section{KESIMPULAN}

Berdasarkan hasil penelitian dan pembahasan yang telah dilakukan, maka dapat ditarik beberapa kesimpulan sebagai berikut:

1. Guru menampilkan gaya hidup dan sikap profesionalimes dalam melaksanakan tugas dan tanggungjawab.

2. Guru MTsN se-Kota Malang dalam menginternalisasi nilai-nilai kehidupaan untuk mewujudkan masyarakat madani sejak dini dimulai dari proses pembelajaran di dalam kelas dengan mengahdirkan pembelajaran yang demokratis, menyenangkan dan terbuka dalam melakukan penilaian.

\section{DAFTAR PUSTAKA}

Agustiar Syah Nur, 2002, Perbandingan Sistem Pendidikan, Lubuk Agung, Bandung.

Moleong, Lexy J. (2007). Metodologi Penelitian kualitatif. Bandung: PT. Remaja Rosdakarya.

Raho, Bernard. (2007). Teori Sosiologi Modern. Jakarta: Prestasi Pustakaraya.

Basrowi, Muhammad, dan Soenyono. 2004. Teori dalam Tiga Paradigma. Surabaya: Yayasan Kampusina.

Naim, Ngainun. (2009). Menjadi Guru Inspiratif; Memberdayakan dan Mengubah Jalan Hidup Siswa. Yogyakarta: Pustaka Pelajar. 
Nurdin, Muhammad. (2004). Kiat Menjadi Guru Profesional. Yogyakarta: Media ArRuzz.

Prasetyo, Bambang. (2006). Metode Penelitian Kuantitatif, Teori dan Aplikasi. Jakarta: Raja Grafindo Persada.

Sudijono, Anas. (2010). Pengantar Statistik Pendidikan, Jakarta: Raja Grafindo Persada.

Arikunto, Suharsimi. (2010). Prosedur Penelitian Suatu Pendekatan Praktik. Jakarta: Rineka cipta.

Madjid, Nurcholis. (2000). Masyarakat Religius. Jakarta: Paramadina. 